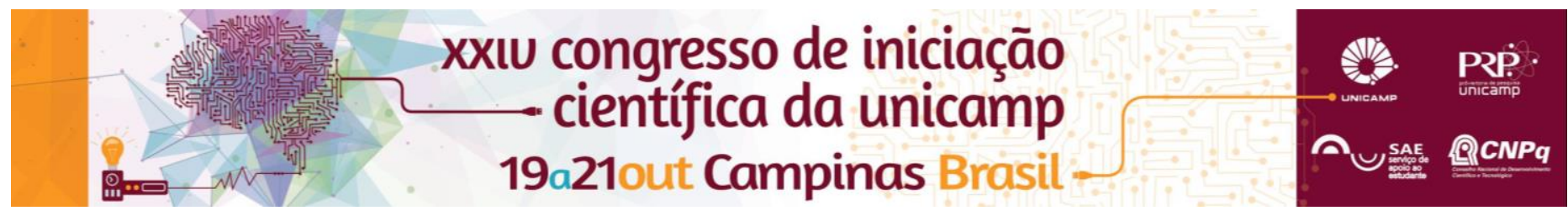

\title{
Dinâmicas da segurança privada em Campinas: limites e conexões de um setor em constante expansão.
}

\section{David Rodrigues Menezes.}

\begin{abstract}
Resumo
Proponho com este trabalho um exame das dinâmicas da segurança privada da cidade de Campinas-SP, considerando a expansão dos serviços de segurança um importante fenômeno da modernidade e variável determinante no entendimento das mudanças ocorridas no espaço urbano e na vida pública das últimas décadas. A partir de análise empírica e etnográfica do setor de segurança privada, busco compreender aspectos fundamentais que marcam o processo de expansão evidenciado no estado de São Paulo. Para além das questões associadas a fenômenos de crescente riqueza das populações e aumento da criminalidade, aponto para o imaginário urbano em torno da violência, o avanço do processo de terceirização do trabalho e o emprego de práticas à margem da lei por parte dos agentes de segurança, como elementos determinantes para a compreensão deste fenômeno.
\end{abstract}

Palavras-chave:

Segurança Privada, Práticas de Policiamento, Trabalho.

\section{Introdução}

Nas últimas cinco décadas, as práticas de policiamento nas cidades modernas têm se constituído enquanto tema de interesse público e importante objeto de estudo das ciências sociais. Ao longo do tempo, o foco de análise expandiu-se das polícias estatais aos processos por meio dos quais, indivíduos e agências, provêm segurança e ordem numa comunidade. Com isso, os serviços da segurança privada passaram a ser identificados como parte fundamental da estrutura de policiamento das sociedades contemporâneas. Dentre as principais mudanças do policiamento nos últimos anos, a expansão da segurança privada é considerada uma das mais marcantes, fazendo-se notar em diferentes contextos sociais e urbanos ao imprimir-lhes uma ordem securitária, e ressignificar os espaços de socialização, consumo, trabalho e moradia. Portanto, sendo a segurança privada um importante fenômeno da modernidade e variável determinante no entendimento das mudanças ocorridas no espaço e na vida pública nas últimas décadas, proponho com este trabalho um exame de suas dinâmicas a partir do caso da cidade de Campinas, situada no interior do Estado de São Paulo.

\section{Resultados e Discussão}

A partir de visitas regulares a associações de classe e conselhos municipais de segurança durante dez meses, estabeleci contato com diversos profissionais da segurança privada, com os quais pude realizar entrevistas e acompanhá-los em sua rotina de trabalho. As reflexões que seguem emergiram da sistematização do trabalho etnográfico e análise bibliográfica. O sentimento de insegurança e as soluções individuais encontradas para a proteção, acabaram por fomentar um heterogêneo, complexo e lucrativo mercado da segurança privada. Sua contínua expansão acabou por moldar a paisagem urbana e o comportamento de uma população cada vez mais reclusa nos espaços privados e supostamente protegida por cercas, muros, cães, câmeras e vigilantes particulares armados. Dentre os principais elementos que contribuíram e caracterizam a expansão da segurança privada, destaco três: i) O imaginário da população em torno de uma violência urbana desmedida e do espaço público tomado como um lugar perigoso e desprotegido; ii) Aumento da DOI: 10.19146/pibic-2016-51494 especialização e emprego de aparatos tecnológicos nos serviços de segurança privada, aliado ao processo de terceirização dos postos de trabalho na segurança; E, por fim, iii) a flexibilização e manipulação interessada das fronteiras entre público e privado, legal e ilegal, em função da valorização conferida ao status policial dentro do mercado de segurança privada e das constantes práticas à margem da lei, praticadas por policiais em 'bico', empresas e vigilantes clandestinos.

\section{Conclusões}

O setor de segurança privada representa apenas uma parcela dos serviços ofertados no mercado de segurança em Campinas. Participam deste mercado atores de diferentes status que, a partir da interação contínua na prática do policiamento, compõem uma complexa malha de segurança socialmente legitimada. Nota-se, portanto, uma expansão da segurança privada em conformidade à flexibilização dos limites legais e das fronteiras entre público e privado, ao aumento das formas de trabalho precário, ao enclausuramento e ressignificação dos espaços urbanos e modos de vida. Nesta conformação, estado e mercado se apoiam e se confundem. Reinventa-se as ferramentas de policiamento e controle social, num movimento quase invisível e que conflui à reprivatização das cidades e da vida urbana moderna.

\section{Agradecimentos}

Agradeço imensamente à orientadora deste trabalho, $\mathrm{Dr} .^{\text {. }}$ Susana Durão, pela confiança, paciência e comprometimento; Ao $\mathrm{CNPq}$, órgão de fomento que tornou possível a realização desta pesquisa; E, por fim, aos interlocutores deste trabalho que, gentilmente, cederam-me seus tempos, ouvidos e vozes.

\footnotetext{
1 Bayley, D. H. Padrões de Policiamento: Uma Análise Internacional Comparativa/Belmonte, R. A. (trad.). Ed. USP, 2006, 272.

${ }^{2}$ Caldeira, T. P. do R. Cidade de muros: crime, segregação e cidadania em São Paulo. São Paulo: Ed. 34 / Edusp, 2000. 400 p.

3 Cubas, V. O. P. Segurança Privada: A expansão dos serviços de proteção e vigilância em São Paulo. Associação Editorial Humanitas: Fapesp, 2005. 176. ${ }^{4}$ Huggins, M. K. CADERNO CRH, Salvador, v. 23, n. 60, 2010, 541-558.

${ }^{5}$ Lopes, C. da S. Como se vigia os vigilantes. Campinas, SP: [s.n.], 2007. Dissertação. IFCH /Unicamp.

6 Tonry, M., Morris, N. (orgs.). Policiamento Moderno/Ghirotti, J. C. (trad.). Ed. USP, 2003, 645 .

7 Zanetic, A. A relação entre as polícias e a segurança privada nas práticas de prevenção e controle do crime. São Paulo, SP: [s.n.], 2010. Tese. FFLCH /USP.
} 